\title{
Sorting mutual funds with respect to process-oriented social responsibility: A FLOWSORT application
}

\author{
Tim Verheyden* and Lieven De Moor
}

${ }^{a}$ KU Leuven, Campus Brussels (HUBrussel), Faculty of Economics and Business, Warmoesberg 26, 1000 Brussels, Belgium ${ }^{b}$ Vrije Universiteit Brussel, Faculty of Economic and Social Sciences and Solvay Business School, Pleinlaan 2, 1050 Brussels, Belgium CHRONICLE ABSTRACT

Article history:

Received February 14, 2014

Accepted May 29, 2014

Available online

Jun X 2014

Keywords:

FLOWSORT

Multi-criteria decision analysis

Socially responsible investing

\begin{abstract}
We establish a robust FLOWSORT-based tool to sort mutual funds with respect to processoriented social responsibility and recommend the use of limiting profiles with open classes. The tool provides an alternative for the limited dichotomous classification of funds, i.e. socially responsible investing (SRI) versus conventional funds. By allowing for more heterogeneity in social responsibility the sorting tool is promising for scholars to improve fund performance measurements, and useful for governments to better regulate the supply of SRI products.
\end{abstract}

(c) 2014 Growing Science Ltd. All rights reserved.

\section{Introduction}

Over the course of the last decade, socially responsible investing (SRI) has become a mainstream investment strategy. Instead of only considering financial objectives, many investors now take into account environmental, social and governance (ESG) issues as well. A typical motivation for SRI is trying to do financially well while doing socially good. However, researchers are interested in the question whether SRI makes financial sense as well. Implementing multi-factor asset pricing regressions, which take into account several factors of risk, most researchers either find a significant underperformance of SRI funds, or no performance differential at all. The problem with the current approach is that no heterogeneity in terms of social responsibility is taken into account, as riskadjusted returns from both a sample of SRI and conventional funds are simply tested for statistical significant differences. Hence the investment universe is falsely reduced to SRI vs. non-SRI. For a more comprehensive overview of the literature, we refer to several excellent review papers (e.g. Margolis \& Walsh, 2003; Orlitzky et al., 2003).

* Corresponding author. Tel: +32472/38.39.09

E-mail address: tim.verheyden@kuleuven.be (T. Verheyden)

C 2014 Growing Science Ltd. All rights reserved. doi: $10.5267 /$ j.ds1.2014.5.004 
A helpful way to circumvent the dichotomous SRI versus conventional fund approach is multi-criteria decision analysis (MCDA). This operations research/decision sciences methodological framework provides the tools to deal with situations that call for simultaneous consideration of multiple conflicting decision factors. Five steps are central to MCDA (Belton \& Stewart, 2002): (1) establishing assessment criteria, (2) defining alternatives, (3) scoring alternatives, (4) weighting criteria and (5) aggregating all of this information. MCDA can address four types of "problematiques" (Roy, 1996): picking, sorting, ranking and describing. In this paper, we present a MCDA sorting tool as a way to distinguish funds based on process-oriented social responsibility criteria. A MCDA-based scoring tool has already been presented by Verheyden and De Moor (2014). The benefit of sorting over scoring tools is that the significance of small performance differentials is reflected in the fact whether a fund is sorted into a superior/inferior category or not.

To the best of our knowledge, this paper is the first attempt to build a MCDA-based tool to sort mutual funds with respect to social responsibility. We find the use of limiting profiles with open classes to be most recommended and design the sorting tool in a way that it can be instrumental for implementation in future mutual fund performance research. For example, scholars could apply multi-factor asset pricing regressions to test for significantly different risk-adjusted returns between the 5 proposed ordered categories, enriching the typical dichotomous distinction between SRI and non-SRI funds. The proposed categories could also be used to construct a factor mimicking zeroinvestment portfolio to control for an "ethics risk factor", following an earlier attempt by Renneboog, Ter Horst and Zhang (2008). Finally, governments might profit from the sorting tool to help regulate the supply of SRI funds (e.g. government-issued SRI labels).

\section{Methodology and data}

To build the sorting tool we implement the five building blocks of the MCDA framework. The first step involves the establishment of assessment criteria.

\section{Table 1}

Hierarchy of criteria and weights from two independent experts

\begin{tabular}{|c|c|c|c|c|c|}
\hline Goal & Criteria & Subcriteria & Sub-subcriteria & Weight E1 & Weight E2 \\
\hline \multirow{20}{*}{ 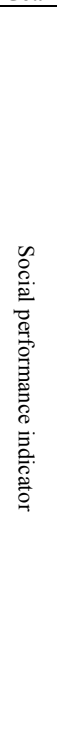 } & \multirow{15}{*}{$\begin{array}{l}\text { Screening } \\
\text { process and } \\
\text { consistency }\end{array}$} & Cl. Priority screening process & & $33.15 \%$ & $2.40 \%$ \\
\hline & & \multirow{3}{*}{$\begin{array}{l}\text { Independent data gathering and } \\
\text { analysis of sustainability }\end{array}$} & $\begin{array}{l}\text { C2. Data gathering and analysis of sustainability by independent external specialists } \\
\text { (e.g. EIRIS) }\end{array}$ & $2.16 \%$ & $23.61 \%$ \\
\hline & & & $\begin{array}{l}\text { C3. Incorporation of SRI principles established by reputable organizations (e.g. UN } \\
\text { SRI, Febelfin) }\end{array}$ & $5.03 \%$ & $3.27 \%$ \\
\hline & & & C4. Information from stakeholders and relevant $N G O s$ & $0.56 \%$ & $6.80 \%$ \\
\hline & & \multirow{3}{*}{ Positive selection criteria } & C5. Best-in-class approach for criteria with respect to ESG criteria & $5.74 \%$ & $9.20 \%$ \\
\hline & & & C6. Use of sector specific positive criteria & $2.76 \%$ & $2.13 \%$ \\
\hline & & & $\begin{array}{l}\text { C7. Investment is principally (> 75\%) in companies that invest in sustainable } \\
\text { technologies }\end{array}$ & $0.49 \%$ & $4.43 \%$ \\
\hline & & \multirow{3}{*}{ Negative selection criteria } & C8. Use of categorical rejects & $7.57 \%$ & $2.47 \%$ \\
\hline & & & C9. Assessment by means of negative criteria & $7.57 \%$ & $5.14 \%$ \\
\hline & & & C10. Exclusion of unsustainable technologies & $7.57 \%$ & $3.56 \%$ \\
\hline & & \multirow{2}{*}{ Monitoring and updates } & $\begin{array}{l}\text { C11. A research teams checks legal and regulatory developments, trends and } \\
\text { behavior of companies such that criteria are in line with recent societal developments }\end{array}$ & $5.25 \%$ & $1.97 \%$ \\
\hline & & & $\begin{array}{l}\text { C12. Monitoring if portfolio is consistent with defined criteria (continuously, sector } \\
\text { specific or occasion specific) }\end{array}$ & $1.75 \%$ & $5.91 \%$ \\
\hline & & \multirow{3}{*}{ Dialogue } & C13. Companies are informed about conclusions selection methodology & $0.24 \%$ & $1.93 \%$ \\
\hline & & & $\begin{array}{l}\text { C14. Active engagement policy (constructive and critical dialogue with companies in } \\
\text { portfolio) }\end{array}$ & $0.51 \%$ & $0.93 \%$ \\
\hline & & & C15. Active voting policy (voting at companies' shareholder meetings) & $2.83 \%$ & $1.34 \%$ \\
\hline & \multirow{5}{*}{$\begin{array}{l}\text { Transparency } \\
\text { and control }\end{array}$} & \multirow{4}{*}{ Transparency } & $\begin{array}{l}\text { C16. Release of qualitative information about the screening process (e.g. applied } \\
\text { screens) }\end{array}$ & $4.00 \%$ & $3.90 \%$ \\
\hline & & & C17. Release of quantitative information about the screening process (e.g. scores) & $4.00 \%$ & $3.90 \%$ \\
\hline & & & C18. Release of current portfolio & $2.23 \%$ & $9.13 \%$ \\
\hline & & & C19. Compliance with external transparency guidelines (e.g. Eurosif/Belsif) & $0.91 \%$ & $1.80 \%$ \\
\hline & & C20. Board of experts & & $5.56 \%$ & $6.25 \%$ \\
\hline
\end{tabular}

As we aim to assess social responsibility on the aggregate level of a fund, and not on the individual level of a single stock, we opt for criteria that describe the investment process of a fund in terms of 
social responsibility, hence we refer to process-oriented social responsibility. Table 1 presents our hierarchy of criteria, which was built from earlier research (Pérez-Gladish \& M'Zali, 2010; De Moor et al., 2012) and directives on SRI by the United Nations (2013) and Febelfin (2012), the Belgian federation of the financial industry.

In the second step we define a set of alternatives, i.e. mutual funds. In this paper, we focus on mutual funds that are available on the Belgian market. The main reason for this is the required set of detailed documentation on the content and design of SRI funds by Febelfin, which enhances step 3 of the process, i.e. the scoring of alternatives. Table 2 presents the list of alternatives, which includes the 24 regulated SRI equity funds offered in Belgium, and a matching sample of 24 conventional equity funds. The matching of funds was realized using six criteria: fund age, fund size, fund type (i.e. accumulation or distribution of gains), geographical orientation, capitalization and investment style.

Table 2

List of alternatives

\begin{tabular}{|c|c|c|c|c|c|}
\hline & SRI Alternative & ISIN-code & & Conventional alternative & ISIN-code \\
\hline A1 & BNP Paribas L1 Equity World Aqua & LU0831546592 & A25 & Legg Mason Batterymarch Global Equity Fund A & IE00B5589395 \\
\hline A2 & Dexia Equities L Sustainable EMU & LU0344047559 & A26 & Dexia Equities L Europe Innovation C & LU0344046155 \\
\hline A3 & Dexia Equities L Sustainable Green Planet & LU0304860991 & A27 & KBC Equity Fund - New Shares & BE0170533070 \\
\hline A4 & Dexia Equities L Sustainable World & LU0113400328 & A28 & BNP Paribas L1 Model 6 Classic & LU0377118962 \\
\hline A5 & Dexia Sustainable Europe & BE0173540072 & A29 & Pictet-European Equity Selection-R & LU0130732109 \\
\hline A6 & Dexia Sustainable North America & BE0173901779 & $\mathrm{A} 30$ & KBC Index Fund United States & BE0166769266 \\
\hline A7 & Dexia Sustainable Pacific & BE0174191768 & $\mathrm{A} 31$ & DWS Invest Top 50 Asia & LU0145648886 \\
\hline A8 & Dexia Sustainable World & BE0946893766 & $\mathrm{A} 32$ & Fidelity Funds - World Fund E & LU0115769746 \\
\hline A9 & IN.flanders Index Fund & BE0175210286 & A33 & KBC Equity Fund - Buyback Europe & BE0174407016 \\
\hline $\mathrm{A} 10$ & ING (L) Invest Sustainable Equity & LU01 19216553 & A34 & KBC Equity Fund - Global Leaders & BE0174807132 \\
\hline A11 & KBC Eco Fund Agri & BE6222656090 & $\mathrm{A} 35$ & Transparant B Equity & BE0935007246 \\
\hline A12 & KBC Eco Fund Alternative Energy & BE0175280016 & A36 & Franklin Global Small-Mid Cap Growth & LU0144644332 \\
\hline $\mathrm{A} 13$ & KBC Eco Fund Climate Change & BE0946844272 & A37 & R Opal Biens Réels F & FR0010563064 \\
\hline A14 & KBC Eco Fund Sustainable Euroland & BE0175718510 & A 38 & KBC Institutional Fund European Equity Classic & BE0176222702 \\
\hline A15 & KBC Eco Fund Water & BE0175479063 & A39 & Vector Navigator $\mathrm{C} 1$ & LU0172125329 \\
\hline A16 & KBC Eco Fund World & BE0133741752 & A40 & AXA Rosenberg Global Equity Alpha Fund A & IE0008366811 \\
\hline A17 & KBC Institutional Fund SRI Euro Equities & BE0175761940 & A41 & Pictet-Europe Index-R & LU0130731713 \\
\hline A18 & KBC Institutional Fund SRI World Equity & BE0168344498 & A42 & SSgA World Index Equity Fund P & FR0000018277 \\
\hline A19 & Parvest Environmental Opportunities & LU0406802339 & A43 & Pictet-Security-P & LU0270904781 \\
\hline A 20 & Parvest Global Environment & LU0347711466 & A44 & GAM Star Global Equity Inflation Focus C & IE00B5BDSJ79 \\
\hline $\mathrm{A} 21$ & Parvest Sustainable Equity Europe & LU0212189012 & A45 & HSBC Global Investment Funds European Equity EC & LU0164863887 \\
\hline $\mathrm{A} 22$ & Petercam Equities Europe Sustainable & BE0940002729 & A46 & Dexia Quant Equities Europe Classic C & LU0149700378 \\
\hline $\mathrm{A} 23$ & Triodos Sustainable Equity Fund & LU0278271951 & A47 & Franklin Global Growth A & LU0122613069 \\
\hline A24 & Triodos Sustainable Pioneer Fund & LU0278272843 & A48 & Universal Invest Quality Growth B & LU0124604223 \\
\hline
\end{tabular}

Next, we need to score the alternatives with respect to the 20 criteria. For every alternative, we assess whether the different criteria apply (1) or not (0) using publicly disclosed information (e.g. fund prospectus, website information, transparency documents from the Febelfin website). The reason for using binary assessments for the individual criteria is to enhance the replicability of the sorting tool for future applications in finance, by avoiding the need for elaborate expert judgments. Since we aggregate all of these assessments across the criteria and the alternatives using MCDA techniques, the eventual scores used to build the categories are no longer dichotomous, and thus better reflect heterogeneity. The performance table can be found in Appendix A.

Prior to calculating the scores, we also need to indicate the relative importance of the different criteria. To do so we ask two independent SRI experts to fill out a questionnaire that asks for pairwise comparisons of the different criteria (cf. Appendix B). Asking two independent experts allows us to test for robustness of results. From these comparisons we can calculate weights for the different criteria using the analytic hierarchy process (Saaty, 1980). This is the only step where we allow for expert judgment. The weights are represented in Table 1.

In our final step we construct categories using FLOWSORT, which draws from PROMETHEE II rankings to assign alternatives to categories using central and limiting profiles. PROMETHEE is the acronym for "Preference Ranking Organization METHod for Enriched Evaluation" and was 
originally developed by Brans and Vincke (1985). It belongs to the outranking school of MCDA methods and starts from the notion that "one solution outranks another if it is at least as good as the other in most respects, and not too much worse in any one respect" (Belton \& Stewart, 2002). Starting from preference degrees that reflect a decision maker's attitude towards the different criteria, PROMETHEE II constructs a complete ranking computing and aggregating unicriterion flows that indicate how one alternative is preferred to another for every single criterion. FLOWSORT, originally developed by Nemery and Lamboray (2008), takes the PROMETHEE II net flow scores to assess the relative position of alternatives with respect to reference profiles and hence assigns the alternatives to completely ordered categories. Two types of reference profiles can be implemented: limiting profiles or central profiles. Limiting profiles define the boundaries between the different categories. We distinguish two options: open and closed categories. On top of the intra-category boundaries, the closed option also requires a boundary on the bottom of the lowest category and a boundary on top of the highest category. That way, alternatives can also be discontinued from any possible category. We choose for open categories, as we want all funds to be assigned to a certain group to account for heterogeneity. Central profiles use representative alternatives for each group, rather than boundaries between groups. An important condition for both types of approaches is that the different categories must dominate each other. We define and implement both open limiting profiles and central profiles, building from expert information and several performance profiles that become apparent from the performance table. From the performance profiles, 5 categories become apparent and thus 4 open limiting profiles and 5 central profiles are established for each expert (cf. Table 3 ). We compare the sorting between both experts to test for robustness.

An important advantage of FLOWSORT over most other sorting techniques (e.g. Doumpos \& Zopounidis; Araz \& Ozkarahan, 2007) is that the allocation of an alternative to a group is independent from the allocation of another alternative. In addition we prefer a PROMETHEE-based ranking approach as the PROMETHEE ranking methodology has proven to be superior to other approaches in assessing process-oriented social responsibility of mutual funds (Verheyden \& De Moor, 2014).

\section{Results and discussion}

We implement the FLOWSORT method in the Smart Picker Pro software. The ordered sorting of the funds in 5 categories can be found in Table 4. Overall we see quite consistent sorting across the two different types of profiles and the two experts, which adds robustness to the results. Most striking is the perfect consistency in the sorting of the top-tier alternatives, i.e. the SRI funds by Triodos and KBC. Triodos is a niche player in the banking industry that promotes itself as "the sustainable bank." $\mathrm{KBC}$ is a traditional commercial bank, but with a long-standing tradition in SRI and a holistic approach to the design of SRI funds. These result are thus not surprising and in line with generally accepted intuition in the industry.

If we compare the results between the inputs provided by both independent experts, we see some differences. Most notably, the ranking within the top group changes between Triodos and $\mathrm{KBC}$. However, the FLOWSORT method has considered this difference to be insignificant and thus sorted SRI funds from both providers in the top category. This kind of additional interpretation of differences in ranking and scores is exactly the added value of FLOWSORT over the ranking and scoring tools. Besides, we see that the limiting profile sorting remains robust over the two experts; for the central profile there are some mild differences in the sorting of lower-tier funds. Despite the rather large differences in the expert judgments, we see that overall results are fairly robust. In addition to the robustness of the limiting profile across both experts, it is also easier to implement because one less predefined profile is required. Taking into account the implementation of these sorting groups in asset pricing regressions, the limiting profiles are also preferred because they yield more balanced groups, whereas the central profiles lead to a disparity of large and small groups. 
Table 3

Limiting (open classes) and central profiles elicited from two experts and performance profiles of the mutual funds

\begin{tabular}{|c|c|c|c|c|c|c|c|c|c|c|c|c|c|c|c|c|c|c|c|c|}
\hline \multicolumn{21}{|c|}{$\begin{array}{c}\text { Expert 1 } \\
\text { Limiting profiles (open classes) }\end{array}$} \\
\hline & $\mathrm{C} 1$ & $\mathrm{C} 2$ & C3 & $\mathrm{C} 4$ & $\mathrm{C} 5$ & C6 & $\mathrm{C} 7$ & $\mathrm{C} 8$ & C9 & $\mathrm{C} 10$ & $\mathrm{C} 11$ & $\mathrm{C} 12$ & $\mathrm{C} 13$ & $\mathrm{C} 14$ & $\mathrm{C} 15$ & $\mathrm{C} 16$ & $\mathrm{C} 17$ & $\mathrm{C} 18$ & $\mathrm{C} 19$ & $\mathrm{C} 20$ \\
\hline Profile 4 & 1 & 1 & 1 & 1 & 1 & 1 & 1 & 1 & 1 & 0 & 1 & 1 & 1 & 1 & 1 & 1 & 0 & 1 & 1 & 1 \\
\hline Profile 3 & 1 & 1 & 1 & 1 & 1 & 1 & 0 & 1 & 1 & 0 & 1 & 1 & 1 & 1 & 1 & 1 & 0 & 1 & 1 & 1 \\
\hline Profile 2 & 1 & 1 & 1 & 1 & 0 & 0 & 0 & 1 & 1 & 0 & 1 & 1 & 1 & 0 & 0 & 0 & 0 & 1 & 1 & 1 \\
\hline Profile 1 & 0 & 0 & 1 & 0 & 0 & 0 & 0 & 1 & 0 & 0 & 0 & 0 & 0 & 0 & 0 & 0 & 0 & 1 & 0 & 0 \\
\hline \multicolumn{21}{|c|}{ Central profiles } \\
\hline & $\mathrm{C} 1$ & $\mathrm{C} 2$ & $\mathrm{C} 3$ & $\mathrm{C} 4$ & $\mathrm{C} 5$ & C6 & $\mathrm{C} 7$ & $\mathrm{C} 8$ & C9 & $\mathrm{C} 10$ & C11 & $\mathrm{C} 12$ & $\mathrm{C} 13$ & C14 & $\mathrm{C} 15$ & $\mathrm{C} 16$ & $\mathrm{C} 17$ & $\mathrm{C} 18$ & C19 & $\mathrm{C} 20$ \\
\hline Profile 5 & 1 & 1 & 1 & 1 & 1 & 1 & 1 & 1 & 1 & 0 & 1 & 1 & 1 & 1 & 1 & 1 & 0 & 1 & 1 & 1 \\
\hline Profile 4 & 1 & 1 & 1 & 1 & 1 & 1 & 0 & 1 & 1 & 0 & 1 & 1 & 1 & 1 & 1 & 1 & 0 & 1 & 1 & 1 \\
\hline Profile 3 & 1 & 1 & 1 & 1 & 0 & 0 & 0 & 1 & 1 & 0 & 1 & 1 & 1 & 0 & 0 & 0 & 0 & 1 & 1 & 1 \\
\hline Profile 2 & 0 & 0 & 1 & 0 & 0 & 0 & 0 & 1 & 0 & 0 & 0 & 0 & 0 & 0 & 0 & 0 & 0 & 1 & 0 & 0 \\
\hline Profile 1 & 0 & 0 & 0 & 0 & 0 & 0 & 0 & 0 & 0 & 0 & 0 & 0 & 0 & 0 & 0 & 0 & 0 & 1 & 0 & 0 \\
\hline \multicolumn{21}{|c|}{$\begin{array}{c}\text { Expert } 2 \\
\text { miting profiles (open classes) } \\
\end{array}$} \\
\hline & $\mathrm{C} 1$ & $\mathrm{C} 2$ & $\mathrm{C} 3$ & $\mathrm{C} 4$ & $\mathrm{C} 5$ & C6 & $\mathrm{C} 7$ & $\mathrm{C} 8$ & C9 & $\mathrm{C} 10$ & $\mathrm{C} 11$ & C12 & C13 & C14 & C15 & $\mathrm{C} 16$ & $\mathrm{C} 17$ & C18 & C19 & $\mathrm{C} 20$ \\
\hline Profile 4 & 1 & 1 & 1 & 1 & 1 & 1 & 0 & 1 & 1 & 1 & 1 & 1 & 1 & 1 & 1 & 1 & 0 & 1 & 1 & 1 \\
\hline Profile 3 & 1 & 1 & 1 & 1 & 1 & 1 & 0 & 1 & 1 & 0 & 1 & 1 & 1 & 1 & 1 & 1 & 0 & 1 & 1 & 1 \\
\hline Profile 2 & 1 & 1 & 1 & 1 & 0 & 0 & 0 & 1 & 1 & 0 & 1 & 1 & 1 & 0 & 0 & 0 & 0 & 1 & 1 & 1 \\
\hline Profile 1 & 0 & 0 & 1 & 0 & 0 & 0 & 0 & 1 & 0 & 0 & 0 & 0 & 0 & 0 & 0 & 0 & 0 & 1 & 0 & 0 \\
\hline \multicolumn{21}{|c|}{ Central profiles } \\
\hline & $\mathrm{C} 1$ & $\mathrm{C} 2$ & $\mathrm{C} 3$ & $\mathrm{C} 4$ & $\mathrm{C} 5$ & C6 & $\mathrm{C} 7$ & $\mathrm{C} 8$ & C9 & $\mathrm{C} 10$ & C11 & $\mathrm{C} 12$ & $\mathrm{C} 13$ & C14 & $\mathrm{C} 15$ & $\mathrm{C} 16$ & $\mathrm{C} 17$ & $\mathrm{C} 18$ & $\mathrm{C} 19$ & $\mathrm{C} 20$ \\
\hline Profile 5 & 1 & 1 & 1 & 1 & 1 & 1 & 0 & 1 & 1 & 1 & 1 & 1 & 1 & 1 & 1 & 1 & 0 & 1 & 1 & 1 \\
\hline Profile 4 & 1 & 1 & 1 & 1 & 1 & 1 & 0 & 1 & 1 & 0 & 1 & 1 & 1 & 1 & 1 & 1 & 0 & 1 & 1 & 1 \\
\hline Profile 3 & 1 & 1 & 1 & 1 & 0 & 0 & 0 & 1 & 1 & 0 & 1 & 1 & 1 & 0 & 0 & 0 & 0 & 1 & 1 & 1 \\
\hline Profile 2 & 0 & 0 & 1 & 0 & 0 & 0 & 0 & 1 & 0 & 0 & 0 & 0 & 0 & 0 & 0 & 0 & 0 & 1 & 0 & 0 \\
\hline Profile 1 & 0 & 0 & 0 & 0 & 0 & 0 & 0 & 0 & 0 & 0 & 0 & 0 & 0 & 0 & 0 & 0 & 0 & 1 & 0 & 0 \\
\hline
\end{tabular}

\section{Concluding remarks}

To the best of our knowledge, this is the first application of the FLOWSORT technique in financial economics. From our analysis, we recommend that limiting profiles with open classes and 5 categories are used in future applications. More concretely, the proposed tool can be used in further SRI performance research to introduce more heterogeneity between funds with respect to social responsibility. One option is to implement multi-factor asset pricing regressions on the 5 categories of funds, instead of just the group of SRI vs. non-SRI funds. This approach will yield 5 risk-adjusted returns that can be tested for significant differences in a more nuanced way. The sorting categories can also be used to construct factor-mimicking portfolios to include a so-called "ethics risk factor" in addition to traditional risk measures (e.g. market risk, size risk, value vs. growth risk and momentum risk). Finally, our tool can be instrumental to assign social responsibility labels to mutual funds, which can be interesting for government regulators looking for curbing the use of the SRI concept for marketing motives. 
Table 4

Sorted funds

\begin{tabular}{|c|c|c|c|c|c|c|c|c|c|c|c|}
\hline \multicolumn{6}{|c|}{ Expert 1} & \multicolumn{6}{|c|}{ 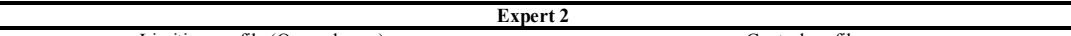 } \\
\hline Limiting profile (open class & & & Central profile & & & Limiting profile (Open class & & & Central profile & & \\
\hline Alternatives & Group & Flow & Alternatives & Group & Flow & 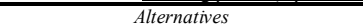 & Group & Flow & Alternatives & Group & Flow \\
\hline A23 - Triodos Sustainable Equity Fund & 1 & 0.29691 & A23 - Triodos Sustainable Equity Fund & 1 & 0.42407 & A11 - KBC Agri & 1 & 0.26150 & A11 - KBC Agri & 1 & 0.37600 \\
\hline A24 - Triodos Sustainable Pioneer Fund & 1 & 0.29691 & A24 - Triodos Sustainable Pioneer Fund & & 0.42407 & A12 - KBC Alternative Energy & 1 & 0.26150 & A12 - KBC Alternative Energy & 1 & 0.37600 \\
\hline A11 - KBC Agri & & 0.22602 & Al1 - KBC Agri & 1 & 0.35318 & A13 - KBC Climate Change & 1 & 0.26150 & A13 - KBC Climate Change & & 0.37600 \\
\hline A12 - KBC Alternative Energy & 1 & 0.22602 & A12 - KBC Alternative Energy & 1 & 0.35318 & & 1 & 0.26150 & A14 - KBC Sustainable Euroland & & 0.37600 \\
\hline A13 - KBC Climate Change & 1 & 0.22602 & A13 - KBC Climate Change & 1 & 0.35318 & A15 - KBC Water & 1 & 0.26150 & A15 - KBC Water & 1 & 0.37600 \\
\hline A14 - KBC Sustainable Euroland & 1 & 0.22602 & A14 - KBC Sustainable Euroland & 1 & 0.35318 & A16 - KBC World & 1 & 0.26150 & A16 - KBC World & 1 & 0.37600 \\
\hline A15 - KBC Water & 1 & 0.22602 & A15 - KBC Water & 1 & 0.35318 & A23 - Triodos Sustainable Equity Fund & 1 & 0.25350 & A23 - Triodos Sustainable Equity Fund & 1 & 0.36800 \\
\hline A16- KBC World & 1 & 0.22602 & A16 - KBC World & 1 & 0.35318 & A24 - Triodos Sustainable Pioneer Fund & 1 & 0.25350 & A24 - Triodos Sustainable Pioneer Fund & 1 & 0.36800 \\
\hline A2 - Dexia Sustainable EMU & 2 & 0.22112 & A2 - Dexia Sustainable EMU & 2 & 0.34828 & A2 - Dexia Sustainable EMU & 2 & 0.21750 & A2 - Dexia Sustainable E & & 0.33200 \\
\hline A4 - Dexia Sustainable World & 2 & 0.22112 & A4 - Dexia Sustainable World & 2 & 0.34828 & A4 - Dexia Sustainable World & 2 & 0.21750 & A4 - Dexia Sustainable World & & 0.33200 \\
\hline A5 - Dexia Sustainable Europe & 2 & 0.22112 & A5 - Dexia Sustainable Europe & 2 & 0.34828 & A5 - Dexia Sustainable Europe & 2 & 0.21750 & A5 - Dexia Sustainable Europe & 2 & 0.33200 \\
\hline A6 - Dexia Sustainable North America & 2 & 0.22112 & A6 - Dexia Sustainable North America & 2 & 0.34828 & A6 - Dexia Sustainable North America & 2 & 0.21750 & A6 - Dexia Sustainable North America & 2 & 0.33200 \\
\hline A7 - Dexia Sustainable Pacific & 2 & 0.22112 & A7 - Dexia Sustainable Pacific & 2 & 0.34828 & A7 - Dexia Sustainable Pacific & 2 & 0.21750 & A7 - Dexia Sustainable Pacific & & 0.33200 \\
\hline A8 - Dexia Sus & 2 & 0.22112 & A8 - Dexia Sustainable World & 2 & 0.34828 & A8 - Dexia Sus & 2 & 0.21750 & A8 - Dexia Sustainable & & 0.33200 \\
\hline 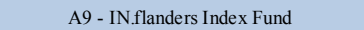 & 2 & 0.22112 & A9 - & 2 & 0.34 & A & 2 & 0.21750 & As & & 0.33200 \\
\hline A17 - KBC SR & 2 & 0.22112 & A17 - KBC SRI Euro Equities & 2 & 0.34828 & A17 - KBC SRI Euro Equities & 2 & 0.21750 & A17 - KBC SRI Euro Ec & 2 & 0.33200 \\
\hline A18 - KBC SRI World Equity & 2 & 0.22112 & A18 - KBC SRI World Equity & 2 & 0.34828 & A18 - KBC SRI World Equity & 2 & 0.21750 & A18 - KBC SRI World Equity & & 0.33200 \\
\hline A21 - Parvest Sustainable Equity Europe & 2 & 0.22112 & A21 - Parvest Sustainable Equity Europe & 2 & 0.34828 & A21 - Parvest Sustainable Equity Europe & 2 & 0.21750 & A21 - Parvest Sustainable Equity Europe & 2 & 0.33200 \\
\hline A22 - Petercam Equities Europe Sustainable & 3 & 0.18768 & A22 - Petercam Equities Europe Sustainable & 2 & 0.31484 & A22 - Petercam Equities Europe Sustainable & 3 & 0.19550 & A22 - Petercam Equities Europe Sustainable & 2 & 0.31000 \\
\hline A10 - ING Susta & 3 & 0.14833 & A10 - ING Sustainable Equity & 2 & 0.27549 & $\mathrm{~A} 1$ - BNPP World Aq & 3 & 0.14850 & A1 - BNPP World A & & 0.26300 \\
\hline & 3 & 0.14092 & & 3 & & & 3 & & & & 0.26300 \\
\hline A19 - Parves & 3 & 0.14092 & arve & 3 & 0.26808 & niti & 3 & 50 & niti & & 0.26300 \\
\hline A20 - Parvest G & 3 & 0.14092 & A20 - Parvest Global Envi & 3 & 0.26808 & A20 - Parvest G & 3 & 0.14850 & A20 - Parvest G & 2 & 0.26300 \\
\hline A3 - Dexia Sustainable Green Planet & 3 & 0.07254 & A3 - Dexia Sustainable Green Planet & 3 & 0.19970 & A3 - Dexia Sustainable Green Planet & 3 & 0.09650 & A3 - Dexia Sustainable Green Planet & 3 & 0.21100 \\
\hline A28 - BNPP Model 6 Classic & 4 & -0.32624 & A28 - BNPP Model 6 Classic & 4 & -0.19908 & A28 - BNPP Model 6 Classic & 4 & -0.18550 & A28 - BNPP Model 6 Classic & & -0.07100 \\
\hline A27 - KBC New Shares & 4 & -0.45460 & A27 - KBC New Shares & 4 & -0.32743 & A27 - KBC New Shares & 4 & -0.25650 & A27 - KBC New Shares & 4 & -0.14200 \\
\hline 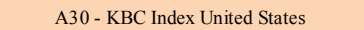 & 4 & -0.45460 & $\mathrm{~A} 30$ - & 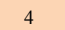 & & $\mathrm{A} 30$. & i & & es & & -0.14200 \\
\hline & 4 & -0 . & & 4 & & & 4 & & & & -0.14200 \\
\hline $\mathrm{A} 34-\mathrm{KBC} \mathrm{G}$ & 4 & -0.45460 & & 4 & & & 4 & & & 4 & -0.14200 \\
\hline A38 - KBC European Equity & 4 & -0.45460 & $\mathrm{~A} 38-\mathrm{KB}$ & 4 & -0.3 & $\mathrm{~KB}$ & 4 & -0.25650 & $\mathrm{~A} 38-\mathrm{KBC}$ Eu & 4 & -0.14200 \\
\hline A26 - Dexia Eu & 4 & -0.47622 & A26 - Dexi & 4 & -0.3 & A26 - Dexi & 4 & -0.49250 & A26 - Dexia Eurc & & -0.37800 \\
\hline $\mathrm{A} 40$ & 4 & -0.4 & & 4 & & $\mathrm{~A} 40$ & 4 & & $\mathrm{~A} 40$ - & & -0.37800 \\
\hline A45 - H & 4 & -0.47622 & 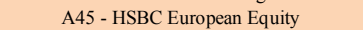 & & & & 4 & & $\mathrm{~A} 45-\mathrm{HS}$ & 4 & -0.37800 \\
\hline & 4 & & & & & & & & & & -0.37800 \\
\hline & 5 & & & & & & & & & 4 & \\
\hline 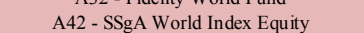 & 5 & & $\mathrm{~A} 42$ & 4 & & A42 & 3 & & & 4 & -0.4 \\
\hline A36 - Fran & 5 & & $\mathrm{~A} 36$ - Fra & 4 & & $36-\mathrm{Fr}_{\mathrm{r}}$ & 5 & & A36 - $\mathrm{Fr}_{1}-r_{1}$ & 4 & -0.41200 \\
\hline & 5 & -0.5 & & 4 & & & 5 & & & 4 & -0.41200 \\
\hline ant B Equity & 5 & -0.56002 & A35 - Transp & 4 & -0.43286 & A29 - Pictet European Equity Sele & 5 & -0.53950 & A29 - Pictet European Equity Selection & 4 & -0.42500 \\
\hline A29 - Pictet Europe & 5 & -0.58545 & A29 - Pictet Euro & & & A31 - DV & 5 & & A31 - DV & 4 & -0.42500 \\
\hline & 5 & -0.58 & & & & & & & & 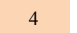 & -0.42500 \\
\hline & 3 & -0. & & & & & & & & 4 & \\
\hline & 5 & & & 5 & & & 3 & & & 4 & -0 \\
\hline & 5 & & & 5 & & A35 - Transp & 5 & & A35 - Tran & 5 & \\
\hline A25 - Legg Mason Batterymarch & 5 & -0.63581 & A25 - Legg Mason Batterymarch & 5 & -0.50865 & A25 - Legg Mason Batterymarch & 5 & -0.57250 & A25 - Legg Mason Batterymarch & 5 & -0.45800 \\
\hline ector Navigator & 5 & -0.63581 & A39 - Vector & & -0.50865 & A39- Vector N & 5 & -0.57250 & A39 - Vector Navigator C1 & 5 & -0.45800 \\
\hline & 5 & & & & & & 5 & & & 5 & \\
\hline niversal Invest Quality C & 5 & -0.63581 & - Universal Invest Quality Growth & & -0.50865 & 8 - Universal Invest Quality C & 5 & -0.57250 & A48 - Universal Invest Quality Growth & 5 & -0.45800 \\
\hline
\end{tabular}

For both types of profiles and both experts, the alternatives are sorted into five categories going from "high" social responsibility to "low" social responsibility. The sorting is based on the PROMETHEE II net flows. 


\section{Acknowledgments}

The authors would like to thank Prof. Yves De Smet and all participants of the International MCDA Workshop on PROMETHEE: Research and Case Studies, for their helpful comments.

\section{References}

Belton, V., \& Stewart, T. J. (2002). Multiple criteria decision analysis: An integrated approach. Boston: Kluwer Academic Publishers.

Behzadian, M., Kazemzadeh, R. B., Albadvi, A., \& Aghdasi, M. (2010). PROMETHEE: A comprehensive literature review on methodologies and applications. European Journal of Operational Research, 200(1), 198-215.

Brans, J. P., \& Vincke, P. (1985). A preference ranking organisation method: The PROMETHEE method for multiple criteria decision-making. Management Science, 31(6), 647-656.

De Moor, L., Devooght, K., \& De Bondt, C. (2012). Een rangschikking volgens het duurzaam en maatschappelijk verantwoord karakter van vier Belgische beleggingsfondsen (A ranking of four Belgian mutual funds according to their sustainable and socially responsible character). Bank-en Financiewezen, 76(2-3), 161-167.

Febelfin. (2012). Aanbeveling inzake duurzame financiële producten (Recommendation concerning sustainable financial products). Consulted at http://www.febelfin.be (February $\left.1^{\text {st }}, 2014\right)$.

Margolis, J. D., \& Walsh, J. P. (2003). Misery loves companies: Rethinking social initiatives by business. Administrative Science Quarterly, 48(2), 268-305.

Nemery, P., \& Lamboray, C. (2007). FLOWSORT: A flow-based sorting method with limiting or central profiles. Top, 16(1), 90-113.

Orlitzky, M., Schmidt, F. L., \& Rynes, S. L. (2003). Corporate social and financial performance : A Meta-analysis. Organization Studies, 24(3), 403-441.

Pérez-Gladish, B., \& M'Zali, B. (2010). An AHP-based approach to mutual funds' social performance measurement. International Journal of Multicriteria Decision Making, 1(1), 103.

Renneboog, L., Ter Horst, J., \& Zhang, C. (2008). The price of ethics and stakeholder governance: The performance of socially responsible mutual funds. Journal of Corporate Finance, 14(3), 302322.

Roy, B. (1996). Multicriteria methodology for decision analysis. Dordrecht: Kluwer Academic Publishers.

Saaty, T. L. (1980). Analytic hierarchy process. Decision Analysis, 50(1), 579-606.

Verheyden, T., \& De Moor, L. (2014). Process-oriented social responsibility indicator for mutual funds: A multi-criteria decision analysis approach. Working Paper. Available at SSRN: http://ssrn.com/abstract=2386566

Zopounidis, C., \& Doumpos, M. (2002). Multicriteria classification and sorting methods: A literaturereview. European Journal of Operational Research, 138(2), 229-246.

United Nations. (2013). The six principles. Principles for Responsible Investment. Consulted at http://www.unpri.org (February $\left.1^{\text {st }}, 2014\right)$. 


\begin{tabular}{|c|c|c|c|c|c|c|c|c|c|c|c|c|c|c|c|c|c|c|c|c|c|}
\hline \multicolumn{2}{|c|}{ Alternative } & \multirow{2}{*}{$\begin{array}{c}\text { C1 } \\
1\end{array}$} & \multirow{2}{*}{$\begin{array}{c}\text { C2 } \\
1\end{array}$} & \multirow{2}{*}{$\begin{array}{c}\text { C3 } \\
1\end{array}$} & \multirow{2}{*}{$\begin{array}{c}\text { C4 } \\
1\end{array}$} & \multirow{2}{*}{$\begin{array}{c}\text { C5 } \\
0\end{array}$} & \multirow{2}{*}{$\begin{array}{l}\mathbf{C 6} \\
0\end{array}$} & \multirow{2}{*}{$\begin{array}{c}\text { C7 } \\
1\end{array}$} & \multirow{2}{*}{$\begin{array}{c}\text { C8 } \\
1\end{array}$} & \multirow{2}{*}{$\frac{\text { C9 }}{1}$} & \multirow{2}{*}{$\frac{\text { C10 }}{0}$} & \multirow{2}{*}{$\frac{\text { C11 }}{1}$} & \multirow{2}{*}{$\begin{array}{c}\text { C12 } \\
1\end{array}$} & \multirow{2}{*}{$\begin{array}{c}\text { C13 } \\
1\end{array}$} & C14 & C15 & C16 & C17 & C18 & C19 & $\mathrm{C20}$ \\
\hline A1 & BNP Paribas L1 Equity World Aqua & & & & & & & & & & & & & & 1 & 1 & 1 & 0 & 1 & 1 & 1 \\
\hline $\mathrm{A} 2$ & Dexia Equities L Sustainable EMU & 1 & 1 & 1 & 1 & 1 & 1 & 0 & 1 & 1 & 0 & 1 & 1 & 1 & 1 & 1 & 1 & 0 & 1 & 1 & 1 \\
\hline A3 & Dexia Equities L Sustainable Green Planet & 1 & 1 & 1 & 1 & 0 & 0 & 1 & 1 & 1 & 0 & 1 & 1 & 1 & 1 & 0 & 0 & 0 & 1 & 1 & 1 \\
\hline A4 & Dexia Equities L Sustainable World & 1 & 1 & 1 & 1 & 1 & 1 & 0 & 1 & 1 & 0 & 1 & 1 & 1 & 1 & 1 & 1 & 0 & 1 & 1 & 1 \\
\hline A5 & Dexia Sustainable Europe & 1 & 1 & 1 & 1 & 1 & 1 & 0 & 1 & 1 & 0 & 1 & 1 & 1 & 1 & 1 & 1 & 0 & 1 & 1 & 1 \\
\hline A6 & Dexia Sustainable North America & 1 & 1 & 1 & 1 & 1 & 1 & 0 & 1 & 1 & 0 & 1 & 1 & 1 & 1 & 1 & 1 & 0 & 1 & 1 & 1 \\
\hline A7 & Dexia Sustainable Pacific & 1 & 1 & 1 & 1 & 1 & 1 & 0 & 1 & 1 & 0 & 1 & 1 & 1 & 1 & 1 & 1 & 0 & 1 & 1 & 1 \\
\hline A8 & Dexia Sustainable World & 1 & 1 & 1 & 1 & 1 & 1 & 0 & 1 & 1 & 0 & 1 & 1 & 1 & 1 & 1 & 1 & 0 & 1 & 1 & 1 \\
\hline A9 & IN.flanders Index Fund & 1 & 1 & 1 & 1 & 1 & 1 & 0 & 1 & 1 & 0 & 1 & 1 & 1 & 1 & 1 & 1 & 0 & 1 & 1 & 1 \\
\hline A10 & ING (L) Invest Sustainable Equity & 1 & 1 & 1 & 1 & 1 & 0 & 0 & 1 & 1 & 0 & 1 & 1 & 1 & 0 & 1 & 0 & 0 & 1 & 1 & 1 \\
\hline A11 & KBC Eco Fund Agri & 1 & 1 & 1 & 1 & 1 & 1 & 1 & 1 & 1 & 0 & 1 & 1 & 1 & 1 & 1 & 1 & 0 & 1 & 1 & 1 \\
\hline A12 & KBC Eco Fund Alternative Energy & 1 & 1 & 1 & 1 & 1 & 1 & 1 & 1 & 1 & 0 & 1 & 1 & 1 & 1 & 1 & 1 & 0 & 1 & 1 & 1 \\
\hline A13 & KBC Eco Fund Climate Change & 1 & 1 & 1 & 1 & 1 & 1 & 1 & 1 & 1 & 0 & 1 & 1 & 1 & 1 & 1 & 1 & 0 & 1 & 1 & 1 \\
\hline A14 & KBC Eco Fund Sustainable Euroland & 1 & 1 & 1 & 1 & 1 & 1 & 1 & 1 & 1 & 0 & 1 & 1 & 1 & 1 & 1 & 1 & 0 & 1 & 1 & 1 \\
\hline A15 & KBC Eco Fund Water & 1 & 1 & 1 & 1 & 1 & 1 & 1 & 1 & 1 & 0 & 1 & 1 & 1 & 1 & 1 & 1 & 0 & 1 & 1 & 1 \\
\hline A16 & KBC Eco Fund World & 1 & 1 & 1 & 1 & 1 & 1 & 1 & 1 & 1 & 0 & 1 & 1 & 1 & 1 & 1 & 1 & 0 & 1 & 1 & 1 \\
\hline A17 & $\mathrm{KBC}$ Institutional Fund SRI Euro Equities & 1 & 1 & 1 & 1 & 1 & 1 & 0 & 1 & 1 & 0 & 1 & 1 & 1 & 1 & 1 & 1 & 0 & 1 & 1 & 1 \\
\hline A18 & KBC Institutional Fund SRI World Equity & 1 & 1 & 1 & 1 & 1 & 1 & 0 & 1 & 1 & 0 & 1 & 1 & 1 & 1 & 1 & 1 & 0 & 1 & 1 & 1 \\
\hline A19 & Parvest Environmental Opportunities & 1 & 1 & 1 & 1 & 0 & 0 & 1 & 1 & 1 & 0 & 1 & 1 & 1 & 1 & 1 & 1 & 0 & 1 & 1 & 1 \\
\hline A20 & Parvest Global Environment & 1 & 1 & 1 & 1 & 0 & 0 & 1 & 1 & 1 & 0 & 1 & 1 & 1 & 1 & 1 & 1 & 0 & 1 & 1 & 1 \\
\hline A21 & Parvest Sustainable Equity Europe & 1 & 1 & 1 & 1 & 1 & 1 & 0 & 1 & 1 & 0 & 1 & 1 & 1 & 1 & 1 & 1 & 0 & 1 & 1 & 1 \\
\hline A22 & Petercam Equities Europe Sustainable & 1 & 1 & 1 & 1 & 1 & 1 & 0 & 1 & 1 & 0 & 1 & 1 & 1 & 0 & 0 & 1 & 0 & 1 & 1 & 1 \\
\hline A23 & Triodos Sustainable Equity Fund & 1 & 1 & 1 & 1 & 1 & 1 & 0 & 1 & 1 & 1 & 1 & 1 & 1 & 1 & 1 & 1 & 0 & 1 & 1 & 1 \\
\hline A24 & Triodos Sustainable Pioneer Fund & 1 & 1 & 1 & 1 & 1 & 1 & 0 & 1 & 1 & 1 & 1 & 1 & 1 & 1 & 1 & 1 & 0 & 1 & 1 & 1 \\
\hline A25 & Legg Mason Batterymarch Global Equity Fund A & 0 & 0 & 0 & 0 & 0 & 0 & 0 & 0 & 0 & 0 & 0 & 0 & 0 & 0 & 0 & 0 & 0 & 1 & 0 & 0 \\
\hline A26 & Dexia Equities L Europe Innovation C & 0 & 0 & 1 & 0 & 0 & 0 & 0 & 1 & 0 & 0 & 0 & 0 & 0 & 1 & 1 & 0 & 0 & 1 & 0 & 0 \\
\hline A27 & KBC Equity Fund - New Shares & 0 & 1 & 1 & 0 & 0 & 0 & 0 & 1 & 0 & 0 & 0 & 0 & 0 & 1 & 1 & 0 & 0 & 1 & 0 & 0 \\
\hline A28 & BNP Paribas L1 Model 6 Classic & 0 & 1 & 1 & 0 & 0 & 0 & 0 & 1 & 1 & 0 & 1 & 0 & 0 & 1 & 1 & 0 & 0 & 1 & 0 & 0 \\
\hline A29 & Pictet-European Equity Selection- $R$ & 0 & 0 & 1 & 0 & 0 & 0 & 0 & 0 & 0 & 0 & 0 & 0 & 0 & 0 & 0 & 0 & 0 & 1 & 0 & 0 \\
\hline A30 & KBC Index Fund United States & 0 & 1 & 1 & 0 & 0 & 0 & 0 & 1 & 0 & 0 & 0 & 0 & 0 & 1 & 1 & 0 & 0 & 1 & 0 & 0 \\
\hline A31 & DWS Invest Top 50 Asia & 0 & 0 & 1 & 0 & 0 & 0 & 0 & 0 & 0 & 0 & 0 & 0 & 0 & 0 & 0 & 0 & 0 & 1 & 0 & 0 \\
\hline A32 & Fidelity Funds - World Fund E & 0 & 0 & 1 & 0 & 0 & 0 & 0 & 0 & 0 & 0 & 0 & 0 & 0 & 1 & 1 & 0 & 0 & 1 & 0 & 0 \\
\hline A33 & KBC Equity Fund - Buyback Europe & 0 & 1 & 1 & 0 & 0 & 0 & 0 & 1 & 0 & 0 & 0 & 0 & 0 & 1 & 1 & 0 & 0 & 1 & 0 & 0 \\
\hline A34 & KBC Equity Fund - Global Leaders & 0 & 1 & 1 & 0 & 0 & 0 & 0 & 1 & 0 & 0 & 0 & 0 & 0 & 1 & 1 & 0 & 0 & 1 & 0 & 0 \\
\hline A35 & Transparant B Equity & 0 & 0 & 0 & 0 & 0 & 0 & 0 & 1 & 0 & 0 & 0 & 0 & 0 & 0 & 0 & 0 & 0 & 1 & 0 & 0 \\
\hline A36 & Franklin Global Small-Mid Cap Growth & 0 & 0 & 1 & 0 & 0 & 0 & 0 & 0 & 0 & 0 & 0 & 0 & 0 & 0 & 1 & 0 & 0 & 1 & 0 & 0 \\
\hline A37 & R Opal Biens Réels F & 0 & 0 & 1 & 0 & 0 & 0 & 0 & 0 & 0 & 0 & 0 & 0 & 0 & 0 & 0 & 0 & 0 & 1 & 0 & 0 \\
\hline A38 & $\mathrm{KBC}$ Institutional Fund European Equity Classic & 0 & 1 & 1 & 0 & 0 & 0 & 0 & 1 & 0 & 0 & 0 & 0 & 0 & 1 & 1 & 0 & 0 & 1 & 0 & 0 \\
\hline A39 & Vector Navigator C1 & 0 & 0 & 0 & 0 & 0 & 0 & 0 & 0 & 0 & 0 & 0 & 0 & 0 & 0 & 0 & 0 & 0 & 1 & 0 & 0 \\
\hline A40 & AXA Rosenberg Global Equity Alpha Fund A & 0 & 0 & 1 & 0 & 0 & 0 & 0 & 1 & 0 & 0 & 0 & 0 & 0 & 1 & 1 & 0 & 0 & 1 & 0 & 0 \\
\hline A41 & Pictet-Europe Index-R & 0 & 0 & 1 & 0 & 0 & 0 & 0 & 0 & 0 & 0 & 0 & 0 & 0 & 0 & 0 & 0 & 0 & 1 & 0 & 0 \\
\hline A42 & SSgA World Index Equity Fund P & 0 & 0 & 1 & 0 & 0 & 0 & 0 & 0 & 0 & 0 & 0 & 0 & 0 & 1 & 1 & 0 & 0 & 1 & 0 & 0 \\
\hline A43 & Pictet-Security-P & 0 & 0 & 1 & 0 & 0 & 0 & 0 & 0 & 0 & 0 & 0 & 0 & 0 & 0 & 0 & 0 & 0 & 1 & 0 & 0 \\
\hline A44 & GAM Star Global Equity Inflation Focus C & 0 & 0 & 0 & 0 & 0 & 0 & 0 & 0 & 0 & 0 & 0 & 0 & 0 & 0 & 0 & 0 & 0 & 1 & 0 & 0 \\
\hline A45 & HSBC Global Investment Funds European Equity EC & 0 & 0 & 1 & 0 & 0 & 0 & 0 & 1 & 0 & 0 & 0 & 0 & 0 & 1 & 1 & 0 & 0 & 1 & 0 & 0 \\
\hline A46 & Dexia Quant Equities Europe Classic C & 0 & 0 & 1 & 0 & 0 & 0 & 0 & 1 & 0 & 0 & 0 & 0 & 0 & 1 & 1 & 0 & 0 & 1 & 0 & 0 \\
\hline A47 & Franklin Global Growth A & 0 & 0 & 1 & 0 & 0 & 0 & 0 & 0 & 0 & 0 & 0 & 0 & 0 & 0 & 1 & 0 & 0 & 1 & 0 & 0 \\
\hline A48 & Universal Invest Quality Growth B & 0 & 0 & 0 & 0 & 0 & 0 & 0 & 0 & 0 & 0 & 0 & 0 & 0 & 0 & 0 & 0 & 0 & 1 & 0 & 0 \\
\hline
\end{tabular}

\section{Appendix B: Questionnaire}

\section{Purpose of the research}

Socially responsible investing (SRI) has experienced a rapid growth over the past decade, reflecting the increasing awareness of investors to environmental, social and governance (ESG) issues. In light of this evolution, one might wonder whether SRI mutual funds perform better than their conventional counterparts. Empirical research considering this question goes back to the early 1970s. However, to this day, the question remains unanswered.The traditional research approach is to implement asset pricing models and to estimate the difference in risk-adjusted returns between conventional and SRI funds. The distinction between both types of funds is traditionally made using a simple dummy variable indicating whether the fund at hand has a particular SRI orientation, which can be found in the fund's prospectus. The main problem with this approach is that it reduces social responsibility to a dichotomous condition. In reality, however, the difference between mutual funds' social responsibility is far more nuanced and continuous, rather than dichotomous. 
In order to help move the SRI performance debate along, we propose a new methodology in classifying funds with respect to their social responsibility. Using an operations research tool called multi-criteria decision analysis (MCDA), we aim to build a social performance indicator for mutual funds, which yields social performance scores on a continuous scale. The main feature of an MCDA indicator is that it can take into account multiple underlying dimensions to a decision problem. In the case of social responsibility of mutual funds, it is possible to define several criteria, an explanation of which can be found in section 1, that together encompass the social responsibility concept. The obtained indicator scores could then be used in further research to better discriminate between mutual funds in examining the SRI performance debate. An important input to the MCDA social performance indicator, is the judgment by an expert on the matter of social responsibility to determine the underlying relationship between the different criteria to calculate a social performance score. Depending on the specific MCDA method, the kind of information required differs. In this document, we ask you to answer several questionnaires, each of which is associated with a certain methodology. Your input is most appreciated.

\section{Criteria}

Before introducing the different questionnaires. We first present the underlying criteria that have been defined to evaluate the social performance of a mutual fund.

\begin{tabular}{|c|c|c|c|}
\hline Goal & Criteria & Subcriteria & Sub-subcriteria \\
\hline \multirow{17}{*}{ 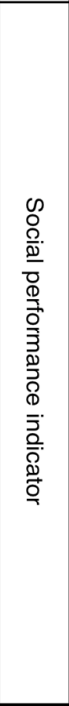 } & \multirow{12}{*}{$\begin{array}{l}\text { Screening process } \\
\text { and consistency }\end{array}$} & Priority screening process & \\
\hline & & \multirow{3}{*}{$\begin{array}{l}\text { Independent data gathering and } \\
\text { analysis of sustainability }\end{array}$} & Data gathering and analysis of sustainability by independent external specialists (e.g. EIRIS) \\
\hline & & & \begin{tabular}{|l} 
Incorporation of SRI principles established by reputable organizations (e.g. UN SRI, Febelfin) \\
\end{tabular} \\
\hline & & & Information from stakeholders and relevant NGOs \\
\hline & & \multirow{3}{*}{ Positive selection criteria } & Best-in-class approach for criteria with respect to ESG criteria \\
\hline & & & Use of sector specific positive criteria \\
\hline & & & Investment is principally (> 75\%) in companies that invest in sustainable technologies \\
\hline & & \multirow[t]{2}{*}{ Negative selection criteria } & Assessment by means of negative criteria \\
\hline & & & Exclusion of unsustainable technologies \\
\hline & & Monitoring and updates & $\begin{array}{l}\text { A research teams checks legal and regulatory developments, trends and behavior of } \\
\text { companies such that criteria are in line with recent societal developments } \\
\text { Monitoring if portfolio is consistent with defined criteria (continuously, sector specific or } \\
\text { occasion specific) }\end{array}$ \\
\hline & & \multirow[b]{2}{*}{ Dialogue } & Companies are informed about conclusions selection methodology \\
\hline & & & Active engagement policy (constructive and critical dialogue with companies in portfolio) \\
\hline & \multirow{5}{*}{$\begin{array}{c}\text { Transparency and } \\
\text { control }\end{array}$} & \multirow{4}{*}{ Transparency } & Release of qualitative information about the screening process (e.g. applied screens) \\
\hline & & & Release of quantitative information about the screening process (e.g. scores) \\
\hline & & & Release of current portfolio \\
\hline & & & Compliance with external transparency guidelines (e.g. Eurosif/Belsif) \\
\hline & & Board of experts & \\
\hline
\end{tabular}

\section{Description of criteria}

Our overall goal is to calculate a social performance score for mutual funds. In our assessment, we make the distinction between two broad sets of criteria. On the one hand, we consider the actual content of the mutual fund by looking at the screening process and its consistency. On the other hand, we look at the transparency, reporting quality and control of the mutual fund. For both of these, we developed sub- and sub-subcriteria, which are simply yes or no questions that can be answered from a funds' prospectus:

- Priority screening process: the fund first executes the screening process, after which a financial analysis is implemented (not the other way around).

\section{- Independent data gathering and analysis of sustainability:}

$\circ$ An independent external specialist company (e.g. EIRIS) gathers the necessary data and analyses sustainability 
- SRI principles established by national (e.g. Febelfin) and international (e.g. United Nations) organizations are referred to and reflected in the portfolio selection criteria

- NGOs and relevant stakeholders are involved in the data gathering process

- Positive selection criteria:

$\circ$ A best-in-class approach (top 30\% performing companies in an industry) is developed with respect to ESG criteria

- Sector specific criteria are used

- Investment is principally $(>75 \%)$ in companies that actively invest in sustainable technologies (e.g. green electricity, $\mathrm{CO}_{2}$ reducing machinery, waste reduction, water quality)

\section{- Negative selection criteria:}

- Categorical rejects using predefined exclusion criteria (e.g. companies involved with nuclear power, tobacco and/or weapons).

- Contestable activities (e.g. gambling, genetically modified organisms, bio hazards) can lead to exclusion, depending on the extent of involvement and the context (more nuanced than categorical rejects).

- No investments in unsustainable technologies, irrespective of possible social or ecological measures.

- Unsustainable technologies: coal plants, nuclear energy, crude oil, coal to liquid, macro-scale hydropower.

- Monitoring and updating:

- A research team checks legal and regulatory developments, trends and behavior of companies such that criteria remain in line with recent societal developments

- Portfolio is monitored for compliance with the set of defined criteria (continuously, sector or event specific)

- Dialogue

- Companies are informed about conclusions of the fund's research and get suggestions for improvement of social performance.

- There is an active engagement policy, which means that there is a constructive and critical dialogue with the companies included in the fund's portfolio in light of positively influencing corporate behavior.

- There is an active voting policy, which means that representatives of the fund attend shareholder meetings, speak up and vote to change companies' behavior for the better.

\section{- Transparency}

- Release of qualitative information about the screening process (e.g. criteria used, description of process).

- Release of quantitative information about the screening process (e.g. scores for individual funds, investment universe).

- The composition of the portfolio is continuously disclosed.

- The fund complies with national and international transparency guidelines (e.g. Eurosif/Belsif).

- Board of experts: a board of experts is consulted to help develop the methodology for building the portfolio. 


\section{Screening and process consistency criterion}

A

B

Priority

Intensity

Independent data gathering and

A or B

Priority screening process analysis of sustainability

Priority screening process

Positive selection criteria

Priority screening process

Negative selection criteria

Priority screening process

Monitoring and updates

Priority screening process

Dialogue

Independent data gathering and analysis of sustainability

Independent data gathering and analysis of sustainability

Independent data gathering and analysis of sustainability

Independent data gathering and analysis of sustainability

Positive selection criteria

Positive selection criteria

Positive selection criteria

Positive selection criteria

Negative selection criteria

Monitoring and updates

Dialogue

Negative selection criteria

Monitoring and updates

Dialogue

Negative selection criteria

Negative selection criteria

Monitoring and updates

Dialogue

Monitoring and updates

Dialogue

\begin{tabular}{cccc}
\hline \multicolumn{2}{c}{ Transparency, reporting and control criterion } & Priority & Intensity \\
\hline A & B & A or B & $(1-9)$ \\
\hline Transparency & Board of experts & \\
\hline
\end{tabular}

Pairwise comparison of sub-subcriteria

\begin{tabular}{|c|c|c|}
\hline \multicolumn{2}{|c|}{ Independent data gathering and analysis of sustainability subcriterion } & Priority Intensity \\
\hline A & B & A or B \\
\hline $\begin{array}{l}\text { Data gathering and analysis of sustainability } \\
\text { by independent external specialists }\end{array}$ & $\begin{array}{l}\text { Incorporation of SRI principles } \\
\text { established by reputable organizations }\end{array}$ & \\
\hline $\begin{array}{l}\text { Data gathering and analysis of sustainability } \\
\text { by independent external specialists }\end{array}$ & $\begin{array}{l}\text { Information from stakeholders and } \\
\text { relevant NGOs }\end{array}$ & \\
\hline $\begin{array}{l}\text { Incorporation of SRI principles established by } \\
\text { reputable organizations }\end{array}$ & $\begin{array}{l}\text { Information from stakeholders and } \\
\text { relevant NGOs }\end{array}$ & \\
\hline
\end{tabular}

\begin{tabular}{lllc}
\hline \multicolumn{1}{c}{ Positive selection subcriterion } & Priority & Intensity \\
\hline \multicolumn{1}{c}{ A } & \multicolumn{1}{c}{ B } & A or B & $(1-9)$ \\
\hline $\begin{array}{l}\text { Best-in-class approach for criteria } \\
\text { with respect to ESG criteria }\end{array}$ & $\begin{array}{l}\text { Use of sector specific positive criteria } \\
\text { Best-in-class approach for criteria } \\
\text { with respect to ESG criteria }\end{array}$ & $\begin{array}{l}\text { Investment is principally }(>75 \%) \text { in } \\
\text { companies that invest in sustainable } \\
\text { technologies }\end{array}$ & \\
$\begin{array}{l}\text { Use of sector specific positive } \\
\text { criteria }\end{array}$ & $\begin{array}{l}\text { Investment is principally }(>75 \%) \text { in } \\
\text { companies that invest in sustainable } \\
\text { technologies }\end{array}$ & \\
\hline
\end{tabular}




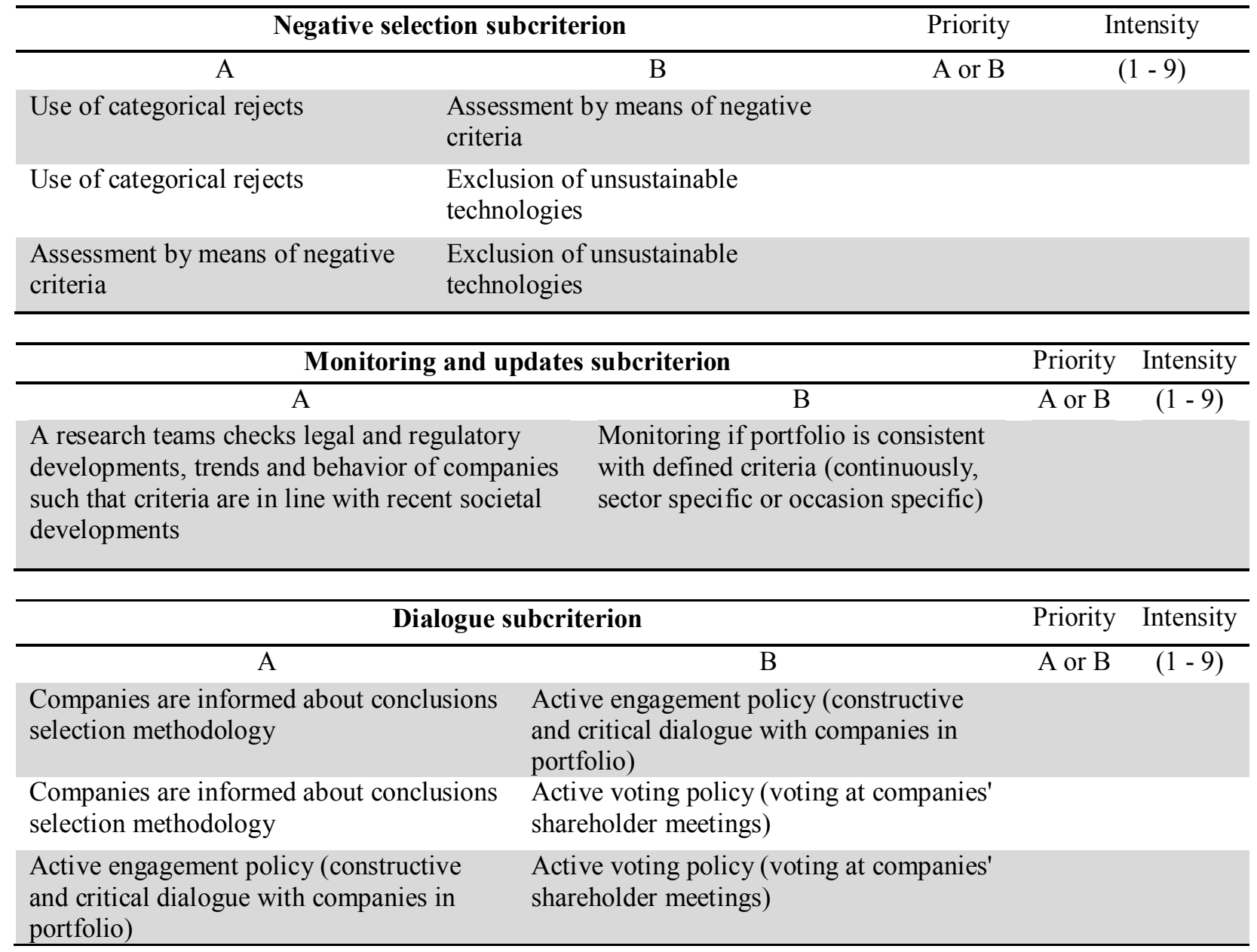

\begin{tabular}{llcc}
\hline \multicolumn{1}{c}{ Transparency subcriterion } & Priority & Intensity \\
\hline \multicolumn{1}{c}{ A } & B & A or B & $(1-9)$ \\
$\begin{array}{l}\text { Release of qualitative information about } \\
\text { the screening process (e.g. applied } \\
\text { screens) }\end{array}$ & $\begin{array}{l}\text { Release of quantitative information } \\
\text { about the screening process (e.g. } \\
\text { scores) }\end{array}$ & \\
$\begin{array}{l}\text { Release of qualitative information about } \\
\text { the screening process (e.g. applied }\end{array}$ & $\begin{array}{l}\text { Release of current portfolio } \\
\text { screens) }\end{array}$ & & \\
$\begin{array}{l}\text { Release of qualitative information about } \\
\text { the screening process (e.g. applied } \\
\text { screens) }\end{array}$ & $\begin{array}{l}\text { Compliance with external } \\
\text { transparency guidelines } \\
\text { Release of quantitative information } \\
\text { about the screening process (e.g. scores) }\end{array}$ & Release of current portfolio \\
$\begin{array}{l}\text { Release of quantitative information } \\
\text { about the screening process (e.g. scores) }\end{array}$ & $\begin{array}{l}\text { Compliance with external } \\
\text { transparency guidelines } \\
\text { Release of current portfolio }\end{array}$ & $\begin{array}{l}\text { Compliance with external } \\
\text { transparency guidelines }\end{array}$ & \\
& & \\
\hline
\end{tabular}

